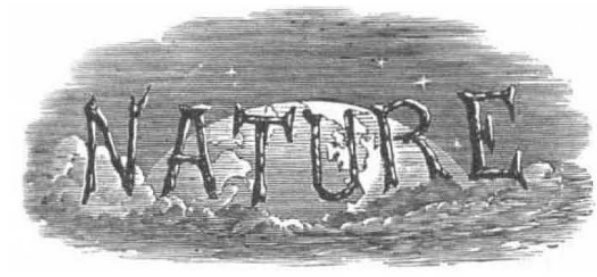

THURSDAY, JANUARY 6, I92I.

Editorial and Publishing Offices:

MACMILLAN \& CO., LTD.,

ST. MARTIN'S STREET, LONDON, W.C. 2.

Advertisements and business letters should be addressed to the Publishers.

Editorial communications to the Editor.

Telegraphic Address: PHUSIS, LONDON.

Telephone Number: GERRARD 8830.

\section{The Cost of Education.}

$\mathrm{T}$ HERE has just been issued the Seventh Report of the Select Committee on National Expenditure, a document, including appendices, of twenty-three folio pages, sixteen of which are devoted to the expenditure on public education, a subject which receives caustic criticism. It would appear that the net cost of education for the year 1920-2I for all forms of education from the public elementary school to the university throughout the United Kingdom is estimated at the vast sum of $97,206,548 l$., of which $60,081,83 \mathrm{rl}$. is derived from taxes and $37,124,7 \mathrm{r} 7 \mathrm{l}$. from rates. This figure is in striking contrast to that of less than ninety years ago, when the local authorities contributed nothing from the rates and the only grant from the Exchequer was one made for the first time in 1834 of 20 ,oool. in aid of school buildings and not of their maintenance. This was the measure of our indifference to the cause of public education, from which the nation has suffered irremediable loss; it enabled more progressive nations with a finer insight into things of real value to compete with us in all departments of civilised life and its varied activities, to our great disadvantage.

Undoubtedly in these strenuous times all possible economies in national and local expenditure ought sedulously to be promoted, but it would be a foolish, not to say a disastrous, policy to limit unduly the expenditure in the means and encouragement of public education, especially for the mass of the people. It is demonstrable that a large percentage of this mass is susceptible to the greatest advantages which can be offered to it of facilities for the highest available education that the country can give. The Education Act of I9I8 and the zeal which prompted and sustained its promoters throughout the lengthy debates in Parliament is the subject of deprecation in the Report, chiefly on the ground of the large expense in which the nation would be involved in carryeng out its provisions at the present difficult time. Surely it is forgotten that expenditure upon education, wisely directed, is, with this qualification, a truly productive effort which will repay the nation a hundredfold within a generation.

The strictures in which the Committee indulges indicate a lack of genuine sympathy with the vital claims of the people to the benefit of a longer continued means of education for their children. Their claims go much beyond the demand for the familiar "three R's"; they require that the best fruits of literature and science shall be brought within their reach. The Committee views with something like dismay "an enthusiasm for education" on the part of the Board of Education, to which Mr. Fisher replies that "a Board of Education which was not enthusiastic for the promotion of education would not deserve to exist." It makes suggestions having for their object the serious curtailment of expenditure under the Education Act of 19x8; such, for example, as would involve the withholding of the proposed continuation schools, one of the most valuable features of the Act; the prolongation of the vicious half-time system which mainly prevails in the textile districts of East Lancashire and West Yorkshire; the stoppage of new developments in the building of schools, both elementary and secondary, in certain towns and rural areas-this last policy has already been largely adopted by the Board of Education during the last five years, having regard to the high prices of materials and of labour, yet, it must be admitted, to the detriment of educational progress--the limitation of means of medical treatment so vital to the welfare of the elementary-school child; and finally, among other important developments made possible by the Act, the curtailment of the means of higher education so essential to the progress and wellbeing of the nation--objects which are set forth so ably in the Report of the Adult Education Committee and by the Workers' Educational Association. 
It must be acknowledged that since the conclusion of the war there has been a remarkable development in public opinion as to the importance and value of education. The demand for secondary education has increased enormously, and the claims for admission to technical colleges and universities have been almost too great for their resources in teaching staff and equipment. In the year 1913-I4 the number of full-time university students in the British Isles was roughly 30,000 , or about 6.5 per Io,, 00 of population. The figures available for the year 1918-rg show that the number of students had almost reached 40,000 . The number of students per 10,000 of population had jumped to 8.6 ; almost one in every thousand was receiving university training.

There has been but slight consideration given in the Report of the Select Committee to the enormous rise in the cost of materials and equipment, especially in reference to the secondary schools and technical institutions, during and since the war, nor has sufficient weight been given to the necessary rise in the salaries of the teaching staff due to the increased cost of living. This item alone accounts for $2 \mathrm{I}, 000,000 l$. in the estimated expenditure. If the schools and the higher institutions of learning are to be staffed efficiently with well educated and trained men and women, adequate salaries and prospects, and an assured provision such as the Teachers (Superannuation) Act affords for the time when they are no longer capable of rendering effective service, must be offered.

Mr. Fisher in a recent interview shows conclusively with regard to the Report in question that there are adequate safeguards in respect of extravagant expenditure both on the part of the Board of Education and on that of the public represented by the ratepayer. The nation will be well advised to encourage by all the means in its power the desire which is so plainly manifest for a longer life in the schools and for the advantages of an efficient secondary and university education for those who are qualified to receive it. Now that the war is over we are entering upon a serious and strenuous time, when all the trained brain power at our command will be needed to meet the competition which we shall assuredly be called upon to face, and after all, as Mr. Fisher truly said in the interview before alluded to, "a nation which can afford to spend 400 millions a year upon drink and roo millions upon tobacco is not quite at the end of its resources."

$$
\text { No. } 267 \text { I, VOL. IO6] }
$$

\section{Territory and Bird Behaviour.}

Territory in Bird Life. By H. Eliot Howard. Pp. xiii + 308. (London: John Murray, 1920.) Price 2 i $s$. net.

$\mathrm{N}$ the publication of his "British Warblers" ${ }_{(1907-14)}$ Mr. H. Eliot Howard took rank as a naturalist of marked ability, as an observer who could be trusted, and as an interpreter well trained in scientific method, fertile in suggestion, cautious in application, and, above all, insistent on the importance of keeping in close touch with the evidence afforded by patient and systematic field-work. A salient outcome of his monograph was a re-grouping of the phenomena presented by birds in their breeding haunts around a concept of "territory." $\mathrm{He}$ has now marshalled the evidence in favour of this hypothesis in a work which neither the biologist nor the comparative psychologist can afford to neglect.

To grasp Mr. Howard's root idea, we must recall the familiar routine of a bird's behaviourand it is clearly with behaviour that observation must primarily deal. There is an orderly sequence the biological value or utility of which is centred in race-maintenance. Within this we can readily distinguish successive phases which are contributory to the routine as a whole. In the life of the wide-range migrant there is departure from the south, arrival in England, settling down in some part of the country, mating, sexual union, nestbuilding, incubation, feeding and rearing of offspring, and then departure from the breeding quarters to the south. All this is familiar enougn. But closer observation discloses other facts. The males arrive in advance of the females; each male: settles down in a restricted area within which some bush or tree is thenceforth his headquarters; the extent of this area is determined by the range of flight in oft-repeated excursions from the headquarters, and constitutes the "territory," which varies in size according to the species; the male bird is intolerant of any intruder into this territory, especially of a male of his species, fights him, and drives him out; he sings with maximum vigour at headquarters before any female is in evidence; this expression in song makes an attractive impression on some hen bird when she arrives in migration from the south; she becomes his mate, lives with him within the territory, and helps to drive out intruders. Mating is consummated, a nest built, and a brood reared within the territory, which affords, in the main, sustenance to the family; and in due season they depart. Now, of course, the sexual act may be regarded as the pivot on which the whole system of behaviour turns. But Mr. Howard contends that, to change 